\title{
HALAL GOVERNANCE IN INDONESIA: THEORY, CURRENT PRACTICES, AND RELATED ISSUES
}

\author{
Fahmi Ali Hudaefi ${ }^{1}$ and Irwandi Jaswir ${ }^{2}$ \\ ${ }^{1}$ Department of Shariah and Management, Academy of Islamic Studies, University of Malaya, \\ Malaysia, alihudzaifi@gmail.com \\ ${ }^{2}$ Professor at International Institute for Halal Research and Training (INHART), International Islamic \\ University of Malaysia (IIUM), Malaysia, irwandi@iium.edu.my
}

\begin{abstract}
Considering Indonesia's target to lead halal industry worldwide, the discussion upon the current practices of halal governance in the country is critical to get into a comprehensive insight. Several major drawbacks within the previous studies on this topic is found along the followings. There has never been a study that has specifically discussed the term of halal governance substantively or comprehensively investigated the subject matters in Indonesia. Driven by this gap, we set out to review halal governance practices in Indonesia by employing a qualitative method of documentary. In doing so, the present paper firstly discusses the substantive materials upon lines of defense in halal governance that covers the four themes, which the present paper particularly reviews as the current practices in Indonesia. From the present discussion, this paper offers the novelty on the explanation of lines of defense in halal governance, and that of the current practices in Indonesia along with the related issues presently associated with it. In addition, this paper further delivers the applicable advises for the improvement of the practices. This study is relevant for the stakeholders of halal industry including the domestic government agencies, practitioners and academics.
\end{abstract}

Keywords: Halal, Halal Governance, Indonesia.

JEL Classification: A12; G39; L59.

\author{
Article history: \\ Received : October 14, 2018 \\ Revised : February 16, 2019 \\ Accepted : February 26, 2019 \\ Available online : March 15, 2019
}

https://doi.org/10.21098/jimf.v5i1.1049 


\section{INTRODUCTION}

Indonesia has become the forefront of halal industry in the world (Detik Finance, 2011; Republika, 2010; Safari, 2018; Satria, 2012). In this regard, the issue is reasonable due to at least several factors; the country has the biggest Muslim population, thus creating high demands over a halal product, and the global confidence towards the halal certificate of Indonesian Council of Ulama (MUI) as claimed by its respective authority (Kemenag - Ministry of Religious Affairs, 2018; Republika, 2009; Setiaji, 2018). For such an objective for Indonesia, one may further inquire: how exactly halal governance has been carried out in the country? To what extent, what are the critical issues currently arising in the practices? With studying this comprehensively, a lesson can be learned for further advancement and hopefully a better assistance the country to accomplish its goals.

To the best of Authors' knowledge, the discussion of the previous studies on the halal topic in Indonesia has not dealt with the practice of halal governance in detail. The existing literature of this subject has discussed the followings; issues on halal certification (Anwar et al., 2018; Prabowo et al., 2015; Rafiki, 2014), issues related to the current halal Act (Limenta et al., 2018), customers' psychological response to a halal product (Maison et al., 2018), factors influencing awareness of a halal product (Nusran et al., 2018), developing model of a halal logistics (Lestari al., 2018), online traceability of a halal product (Sayogo, 2018), analysis of halal tourism and brand image (Surya et al., 2018) and a massive study on halal and science. To this extent, a detailed discussion upon halal governance in Indonesia has suffered from the existing scholarly works.

Of which Indonesia has a target to lead halal industry worldwide; therefore a comprehensive systematic discussion on halal governance in the country is critical. As such, the present paper aims at reviewing the relevant literature discussing the subject matters. The novelty credited by this work shall highlight the practice of halal governance in Indonesia along with the issues associated, and to some extent, this study shall come out with hands-on advises for future improvement of the national practices.

This study employs a method of Internet documentary; hence, the data is limited to that of available online as per needed. Further accuracy shall be done for the comments given by the related parties. To this end, section two shall review theoretical ground related to halal governance, section three shall brief the research method, and the rest sections shall cover result, discussion, conclusion and recommendation.

\subsection{Purpose of the Study}

Along with Indonesia's motivation to become the center of halal industry worldwide, an understanding of halal governance and its current practices in the domestic level is central due to some fundamental issues. This paper aims to firstly establish the term halal governance substantively, and further engages this as the benchmark to review that of the current practices in Indonesia. Following this, the present paper further discusses critically the practices, and generates a scholarlydriven recommendation for the enhancement of the national practices. 


\section{LITERATURE REVIEW}

\subsection{Understanding of Halal and the Related Issues in Indonesia}

Halal refers to the faith of Muslim which means permissible or accepted by the law of Islam, and its opposite term is haram by which is prohibited or is also called non-halal. Between halal and haram is mashbooh or uncertainty (Ahmad et al., 2018; Saad et al., 2016; Wilson \& Liu, 2010). In Islam, concept of halal in food is followed by thoyyib which refers as nutritious, quality and safe (Ahmad et al., 2018). Nasaruddin et al. (2011) explained its concept is not limited to only consumable goods, rather it covers the life-system of a Muslim. Halal is mentioned in al-Qur'ān surah (chapter) al-Baqarah:168, and in al-Hadiths (words of the Prophet) which some of them narrated by Abū Hurairah (Saad et al., 2016).

In the last few decades, halal in the global industry has been growing up significantly covering both food and non-food industry; such as cosmetics, fashion, financial services, and even tourism (Saad et al., 2016). Studies have highlighted the potential of global halal market is at US\$150 billion according to Fischer (2012) and E. Rios et al., (2014), and is at US\$3.1 trillion per year as informed by Jaswir (2018). Specifically in Indonesia, that of the potential market is at US\$10 billion (Sugiarti 2016).

Parallel with Indonesia's halal potential, some related issues have been arising. Prabowo et al. (2015) addressed that of the factors hindering halal certification in the local context. With considering the perspectives of the local stakeholders, they explained a lack of information and insufficient supervision, a lack of public awareness, a lack of competent human resources, and even a government related agency was less aware of their role, were among the issues occurring in the local halal industry (Prabowo et al., 2015). Further, Limenta et al. (2018) highlighted several substantive issues of Indonesia's Halal Act. Concerning this, they recommended an amendment and clarification for the scope of halal products governed in Article 4 of the current halal Act.

In the pursuance of Indonesia's target to lead halal industry worldwide along with the above issues, a review of the current practices of halal governance in the country becomes critical. By doing so, a comprehensive understanding of the practices will be well documented scientifically together with a germane recommendation for a further advancement. And to some extent, this shall be relevant for the related government agencies to either establish or further improve the existing halal related policies.

\subsection{Establishing the Term of Halal Governance}

Governance in Cambridge Dictionary is defined as a way in which an organization is managed at the highest level, meanwhile in Business Dictionary is defined as the establishment of policies, and constant monitoring of their appropriate implementation by the related authority. UNESCO explained governance as the designed structures and processes to confirm accountability, transparency, responsiveness, the rule of law, stability, and other related matters. Having explained this, thus the main idea for halal governance may be established from this ground. 
Developing the term halal governance may further be related to the history of the term corporate governance. This corporate governance has gained an extensive attention from the global academics, governments and regulators since 1990s due to several issues; dissatisfaction of shareholders towards the underperforming firms, and that of related to human hazard causing the instability of an organization (Ginenza \& Hamid, 2015). With this phenomenon resulting the brainchild of the term corporate governance, it might accurately represent the current issues of halal industry, such as the breach of halal fundamentally. To respond this emerging issue, a further explanation for the term of halal governance is significant to establish.

\subsubsection{The Previous Study}

Of which the existing study explains the term halal governance in detail remains absent, this work refers to Ahmad et al. (2018) to establish so, and to further review that of the current practices in Indonesia. Ahmad et al. (2018) outlined the control system of halal food in Malaysia under the five themes that are: one; legislation and regulation. Two; control management of halal. Three; inspection and enforcement of halal. Four; halal laboratory. And five; information, education, communication and training (IEC) for halal. Figure 1 illustrates the lines of defense in halal governance adapted from Ahmad et al. (2018).

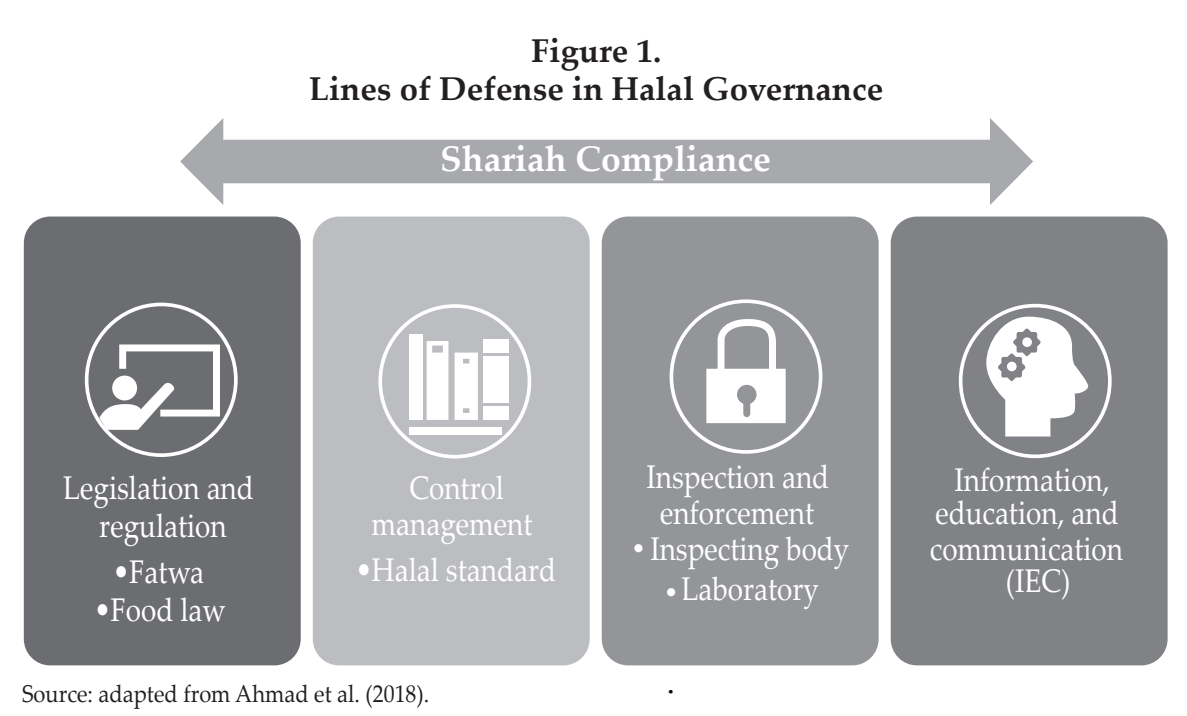

Thoroughly, Ahmad et al. (2018) explored the Malaysia's experience in establishing the control system of halal food industry. Under the five themes, they reviewed the way halal has been executed by the local industry from the regulation to the industry players. From their discussion, it makes sense to adapt their theme of halal food control system as the lines of defense in halal governance since a substantive material has been credited so. Figure 1 depicts the primary aim of lines of defense in halal governance is to establish a shariah-compliant practice in the industry, particularly to perform halal according to its fundamental. 
Adapting Ahmad et al. (2018), this study has further adjusted the laboratory theme which was merged into the inspection and enforcement due to the substantive ground. Discussed upon the understanding of halal, governance, a brief history of the term corporate governance, and the adapted study of Ahmad et al. (2018) as per above, thus, the term of halal governance has been established here. With the ground as of Figure 1, the following research questions are addressed; "how halal governance in Indonesia has been practiced, and what are the related issues currently arisen?"

\section{METHODOLOGY}

\subsection{Research Design}

Turning now to the research method, this work employed a qualitative research to explore the practice of halal governance in Indonesia. A qualitative approach offers an effective way of characterizing and identifying a central phenomenon which the variables are needed for further exploration (Creswell, 2012). With a central phenomenon of this study is halal governance, thus a qualitative method is best suited to explore its variables for describing this phenomenon (Clark \& Creswell, 2015).

Correspondingly, the four themes of halal governance as in Figure 1 were employed for the guideline to review that of the current practices in Indonesia. For this, Authors collected the relevant documents available in online to study the subject matters. Reason being so is for convenient and accessible purposes.

\subsection{Data Collection and Analysis Method}

This paper employed the method of documentary, in which a document is a simply written text (Mogalakwe, 2006), refers to both public and private documents including that of available online (Creswell, 2012). A major benefit of a document is well-organized, accessible, less costly, and stable (Bowen, 2009), and provides the advantage of being insightful information from the relevant participants and are ready for further analysis (Creswell, 2012). A document analysis include skimming, reading and interpretation (Bowen, 2009).

A content analysis was further engaged here to study the relevant documents, which Bowen (2009) explained as the procedure of classifying the information related to the central question of a research. This content analysis is applicable to all contexts for making replicable and valid inferences from a text, including the text downloaded from the internet (Krippendorff, 2004; Neuendorf, 2001). Following this, a thematic analysis was executed to further select the data based on the adapted theme of halal governance. In addition, the critical analysis was undertaken throughout contextualizing the topic with the elaboration of background information, followed with analyzing the documents for the exploration of the related issues, together with discussing the possible alternative responses, and finalized with delivering the implication and the hands-on recommendation (University of Bradford).

The procedure of reviewing the documents here was begun with studying the related literature to establish a relevant understanding of the term halal 
governance. With so, a theoretical ground of halal governance was proposed. The documents were further studied to explore that of the practices in Indonesia, and to code the data based on the employed themes as of Figure 1. After this, a further discussion was conducted to critically analyze the issues associated with the practices. Conducted so, an applicable recommendation was credited for advancing the practices. Figure 2 illustrates this model of findings.

Figure 2.

Model of Findings

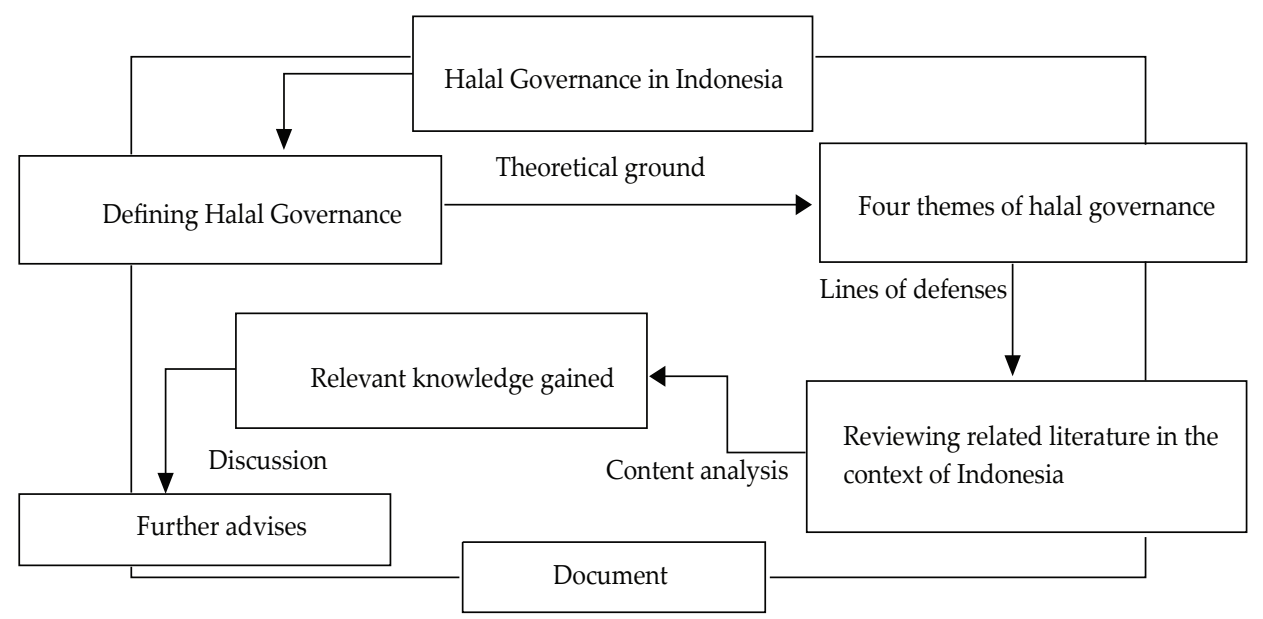

Source: Authors' document.

Of which the four themes of halal governance as of Figure 1 were employed here, this section further discusses in detail those of the theory related to the lines of defense in halal governance, along with the current practices in the context of Indonesia. Recalling Authors have employed the method of documentary; thus, the current data was limited to that of information available online.

\subsection{Legislation and Regulation}

\subsubsection{Halal Act in Indonesia}

A legislation refers to the law issued by an official governing body (Cambridge Dictionary), while a regulation carries out specific piece of legislation (Business Dictionary). Law and regulation for a halal product is crucial for consumer protection, ensuring moral obligation of producers, and gaining a competitive advantage in both local and global market (Ramli, 2010). Legislation and regulation are critical for the first line of defense in halal governance. Citing Wiyono (2013) who highlighted a scandal voiding halal in Indonesia, Prabowo et al. (2015) stated lack of government regulation had caused so.

Prior to the existing halal Act, Prabowo et al. (2015) informed the term halal within Indonesia's law can be found under the Livestock and Animal Health Act No. 6 of 1967, Health Act No. 23 of 1992, Food Act No. 7 of 1996, No. 18 of 2012, 
and Consumer Protection Act No. 8 of 1999. The Act of Livestock and Animal Health was the starting point of Indonesia to discuss halal from the governmental level. This legislative discourse has gained an extensive attention in 2012 through Food Act No. 18. Informed in Table 1, the seven words of halal can be found within this Act.

Table 1.

\section{Halal Term within Related Act of Indonesia}

\begin{tabular}{|c|c|}
\hline Act & Details \\
\hline $\begin{array}{l}\text { Livestock and } \\
\text { Animal Health Act } \\
\text { No. } 6 / 1967\end{array}$ & $\begin{array}{l}\text { Term halal within this act can be found in article } 21 \text {. This act } \\
\text { requires the isolation between halal } \neg \text { food and non-halal food. }\end{array}$ \\
\hline Food Act No. 7/1996 & $\begin{array}{l}\text { Term halal within this act can be found in section } 4 \text { article } 30 \text {. This } \\
\text { act administrates food labeling and marketing include halal label. }\end{array}$ \\
\hline Food Act No. 18/2012 & $\begin{array}{l}\text { Term halal within this act can be found within } 5 \text { articles as following; } \\
\text { - Article } 69 \text { governs food safety is conducted through several } \\
\text { ways including with halal product assurance for those required. } \\
\text { - Section } 8 \text { article } 95 \text { states central and local government } \\
\text { supervise the implementation of halal assurance system for the } \\
\text { required products. } \\
\text { - Article } 95 \text { point } 2 \text { mentions the implementation of halal } \\
\text { assurance system is conducted under several conditions of law. } \\
\text { - Article } 97 \text { point } 3 . e \text { administrates label of product should be } \\
\text { written in Bahasa Indonesia including for halal label. } \\
\text { - Article } 101 \text { point } 1 \text { governs whereby producers who label halal } \\
\text { their products are responsible for its validity. } \\
\text { - Article } 105 \text { point } 1 \text { controls whereby those who market their } \\
\text { products as halal are responsible for its validity. }\end{array}$ \\
\hline $\begin{array}{l}\text { Consumer Protection } \\
\text { Act No. 8/1999 }\end{array}$ & $\begin{array}{l}\text { Halal term can be found in section } 4 \text { Article } 8 \text {. This governs } \\
\text { prohibited acts including those who produce by way not halal but } \\
\text { label their products as halal. }\end{array}$ \\
\hline
\end{tabular}

Source: adapted from related documents

Remarking Indonesia's experience of almost five decades to finally release a specific legislative law of halal, is paradox of which the Country has the biggest Muslim population worldwide, yet it took a half-century to issue so. Nevertheless, with Halal Product Assurance Act (JPH) No. 33 of 2014 (Limenta et al., 2018), Indonesia has move forward bringing halal into its constitutional level. Endorsed so, the discussion among the Indonesian legislators had taken the period of nine years (Jundi \& Imam S, 2017) to finally release it on 25 September 2014 (Adam, 2017).

As of Table 2, the JPH covers 11 sections consisting of 68 articles that administrate halal for both industry and society of Indonesia. With this Act, halal certification in Indonesia becomes mandatory. To some extent, this comprehensive Act may disprove the statement of Prabowo et al. (2015), who mentioned a lack of government laws and regulation was among the factors hindering halal certification in the local context. 
Table 2.

Halal Act (JPH) No. 33 of 2014

\begin{tabular}{|c|c|c|}
\hline Sections & Articles & Matters Administrated \\
\hline One & $\begin{array}{l}4 \text { articles } \\
(1-4)\end{array}$ & $\begin{array}{l}\text { General requirements; } \\
\text { - Halal product is a product declared halal according to Islamic law (article } 1 \text { point 2); } \\
\text { - All products entered into and traded in Indonesia must be halal-certified (article 4). }\end{array}$ \\
\hline Two & $\begin{array}{l}12 \text { articles } \\
(5-16)\end{array}$ & $\begin{array}{l}\text { Administrator of JPH; } \\
\text { - Related Ministry and local administrative as BPJPH (article } 5 \text { point 2); } \\
\text { - } 10 \text { duties of BPJPH (article 6); BPJPH to work together with related agencies in } \\
\text { executing the } 10 \text { duties (article 7-11); } \\
\text { - Matters related to LPH (article 12-13); } \\
\text { - Matters related to halal auditor (article 14-15). }\end{array}$ \\
\hline Three & $\begin{array}{l}6 \text { articles } \\
(17-22)\end{array}$ & $\begin{array}{l}\text { Ingredient and process of halal product; } \\
\text { - List of haram ingredient (article 18); } \\
\text { - Animal slaughter according to Islamic (article 19); } \\
\text { - Location, place, and equipment in halal production must be separated out from that of } \\
\text { non--halal (article 21), otherwise warning letter and fine will be issued for those who } \\
\text { break this (article 22). }\end{array}$ \\
\hline Four & $\begin{array}{l}6 \text { articles } \\
(23-28)\end{array}$ & $\begin{array}{l}\text { Matters related to businessperson; } \\
\text { - Right for businessperson (article 23), obligation of businessperson when applies for } \\
\text { halal certificate (article 24), requirements for those entrepreneurs who already had the } \\
\text { certificate (article 25); } \\
\text { - Administrative penalty for those who break article } 25 \text { (article 27) } \\
\text { - Matters related to halal supervisor (article 28). }\end{array}$ \\
\hline Five & $\begin{array}{l}17 \text { articles } \\
(29-45)\end{array}$ & $\begin{array}{l}\text { Procedure obtaining halal certificate; } \\
\text { - Documents for halal certification (article } 29 \text { point 2); } \\
\text { - Checking and examination by halal auditor (article 31-32); } \\
\text { - Decision on halal-ness a product by MUI (article 33); } \\
\text { - Issuance of halal certificate by BPJPH (article 35-36); } \\
\text { - Matters related to halal label (article 37-41); } \\
\text { - Halal certificate renewal (article 42-43); } \\
\text { - Fees of halal certificate to be borne by applicant, in case the applicant is a micro and } \\
\quad \text { small (SMEs) entrepreneur, the fees can be facilitated by other parties (article 44). }\end{array}$ \\
\hline Six & $\begin{array}{l}3 \text { articles } \\
(46-48)\end{array}$ & $\begin{array}{l}\text { International cooperation; } \\
\text { - One of international cooperation is halal certificate recognition (article } 46 \text { point 2); } \\
\text { - Foreign products are subject to this act (article } 47 \text { point 1); } \\
\text { - Administrative penalty for foreign products who break the law governed within the act } \\
\text { (article 48). }\end{array}$ \\
\hline Seven & $\begin{array}{l}4 \text { articles } \\
(49-52)\end{array}$ & $\begin{array}{l}\text { Surveillance related matters; } \\
\text { - Supervising controls related parties (article } 49 \text { - 52). }\end{array}$ \\
\hline Eight & $\begin{array}{l}3 \text { articles } \\
(53-55)\end{array}$ & Participation of the community related matters. \\
\hline Nine & $\begin{array}{l}2 \text { articles } \\
(56-57)\end{array}$ & $\begin{array}{l}\text { Criminal provisions related matters; } \\
\text { - Producers whose their products already halal-certified but fail to maintain halal-ness } \\
\text { of their products are subject to maximum of } 5 \text { year imprisonment, or fined Rp } 2 \text { billion } \\
\text { (USD } \$ 131.900 \text { ) (article 56); } \\
\text { - The informed formula by the entrepreneurs during the process of halal certification is } \\
\text { confidential. Maximum of } 2 \text { years imprisonment, or fined Rp } 2 \text { billion (USD } \$ 131.900 \text { ) } \\
\text { for the related parties who break this (article 57). }\end{array}$ \\
\hline $\begin{array}{l}\text { Ten and } \\
\text { Eleven }\end{array}$ & $\begin{array}{l}6 \text { and } 5 \\
\text { articles } \\
(58-68)\end{array}$ & $\begin{array}{l}\text { Matters related to transitional provisions. } \\
\text { Closing and related substantive matters. }\end{array}$ \\
\hline
\end{tabular}

Note: JPH is Halal Product Assurance, BPJPH is Agency of Administrator for Halal Product Assurance, LPH is Agency of Halal Inspection related matters, and MUI is Indonesian Council of Ulama. Source: Simplified from Halal Product Assurance (JPH) Act No. 33/2014. 
The controversial issues have been arising subsequent to the issuance of the $\mathrm{JPH}$. Those issues can be categorized into two; subjective and substantive issues. Of the three subjective issues were documented from the online news including; the incapability of SMEs entrepreneur for halal certification, the institution deciding of the halal-ness a product, and the halal certification of clothing and other related non-consumable goods.

Situmorang (2016) reported the inability of the SMEs for halal certification due to expensive fee charged. In this, with referring to the Article 44 of JPH that states other parties can facilitate those kinds of entrepreneurs for the certification, thus, such the issue arisen is of no consequence. Folia (2017) wrote the confusion of the institution making the decision on the halal-ness of a product. This issue may be caused by a lack of careful understanding of the Act. The Article 33 of JPH clearly governs whereby MUI decides the halal-ness of a product. Having stated this, hence, the issue is questionable. Setyawan (2016) informed halal certification for non-food items, such as clothing and other related materials. This issue may relate to the Article 4 of JPH and is reasonably raised due to the unspecified criteria of the products governed under the Act. However, certifying halal the clothing and its related materials is rational, because some of them are made from the pig skin (Kaufman \& Smith, 2000; Leather Dictionary, 2018).

Meanwhile, the substantive issues in the wake of JPH can be found in Limenta et al. (2018). They concerned on the consistency between JPH with The Agreement on Technical Barriers to Trade (TBT) of the World Trade Organization (WTO). The study highlighted the potential of being inconsistent between JPH with Article 2 point 1 of the TBT agreement (Limenta et al., 2018). The study proposed an amendment to be made within Article 4 of the Act, which they argued of being broad and equivocal. From their analysis, the issue is arisen accurately due to the practical matters. Further, another substantive issue of JPH may relate to its Article 6.c and Article 29 point 1. In this, Article 6.c administrates BPJPH as the authority to issue and revoke halal certificate of a product, while Article 29 point 1 controls the starting point of halal certification procedure. With so, such the service that previously was done by MUI is shifted to BPJPH for applying, issuing and revoking a halal certificate.

MUI has established its hands-on experience of the domestic halal certification since almost 3 decades of the operation. Therefore, harmonizing roles of BPJPH with the existing body under MUI shall make sense for effective and efficient practices. In this, the established body under MUI may simply be appointed as BPJPH for reducing the bureaucracy. Even per September 2018 according to Harimurti (2018), MUI is still serving the domestic halal certification as BPJPH has not yet operated.

\subsubsection{Fatwa on Halal}

Ahmad et al. (2018) explained a fatwa is another critical component in a legislation and regulation for halal in addition to the conventional legal texts. Fatwa is a religious practice of a Muslim in search of new Islamic ruling for a special case (Mehmood, 2015). It is an authoritative legal opinion from a Mufti or a legal scholar (Oxford Islamic Studies), and is also a guideline to understand way of refinement 
of an Islamic law (HDCGlobal). A fatwa takes the position when a contemporary issue occurs requiring a new ruling. It is formed through ijma (a consensus of legal opinion) and qiyas (analogy reasoning) conducted by Ulama (Muslim Scholars), thus, a fatwa is the product of ijma (Ahmad et al., 2018).

Fatwa Committee of MUI is the authorizing body to issue a fatwa in Indonesia. MUI is a non-governmental organization (NGO) covers Indonesian Muslim scholars established on 26 July 1975 in Jakarta. MUI operates across the three structural state of Indonesia including national, provincial and regencial level. In case a fatwa is requested, MUI from these levels of state is the authorizing body to issue so. Figure 3 depicts order of fatwa decision performed by MUI, including that of the issuance of fatwa halal.

Figure 3.

\section{Method of Fatwa Decision in Indonesia}

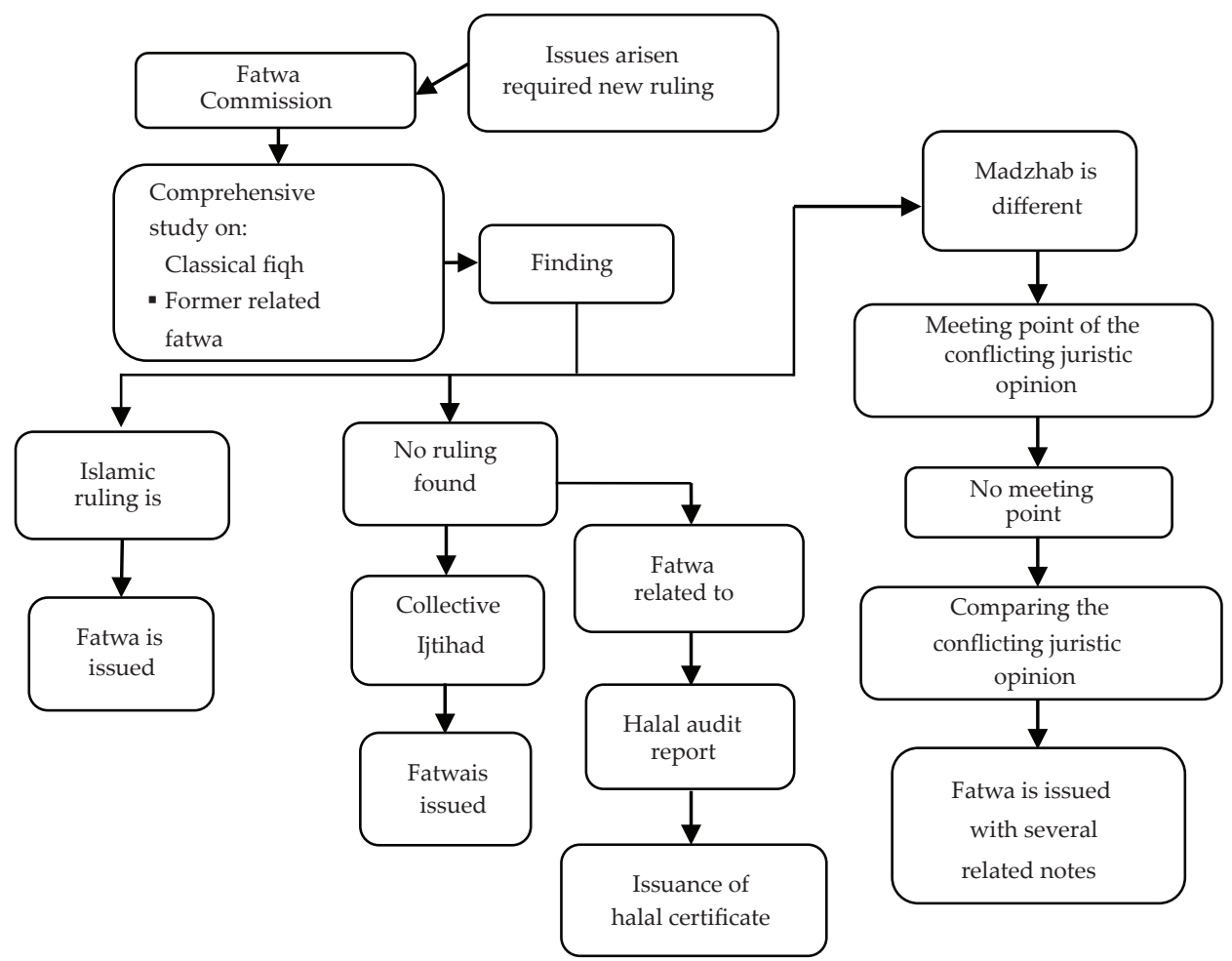

Source: Adapted from MUI PO No. 5/2015 Section 3 Article 5 and 6, Section 7 Article 20 and 21.

MUI has 13 organizational guidelines (PO) ruling its operation. The guideline ruling a fatwa decision is governed under PO No. 5 of 2015. The section 7 of the PO elaborates the fatwa of halal for a product is decided based on the report of halal audit under the MUI's fatwa commission meeting. In the process of auditing, Fatwa commission of MUI assists the auditor should a specific expertise is required (Majelis Ulama Indonesia). 
Over decades, the fatwa of MUI has responded to the contemporary issues arisen within the Indonesian society. Table 3 highlights the fatwa of MUI related to the social issues that has occurred in the local context. In particular, the number of approximately 16 fatwas was released answering them. Those issued fatwas have provided an enormous contribution, unexceptionally for the local industry to be compatible with fundamental of halal.

Table 3.

List of MUI Fatwa Related to Halal Contemporary Issues

\begin{tabular}{|c|c|c|}
\hline Issues Arisen & Year & Fatwa Decision \\
\hline Narcotics abuse & $\begin{array}{l}\text { February 5, } \\
1976\end{array}$ & - Narcotics abuse is haram. \\
\hline Animal slaughtering & $\begin{array}{l}\text { October 18, } \\
1976\end{array}$ & - Animal slaughtering by way stunning is permissible and halal. \\
\hline $\begin{array}{l}\text { Food and beverage } \\
\text { mixed with that of } \\
\text { haram }\end{array}$ & $\begin{array}{l}\text { May } 26 \text { - June } \\
1,1980\end{array}$ & $\begin{array}{l}\text { - Food and beverage mixed with haram components are haram; } \\
\text { - Food and beverage are doubted to mix with haram component to be } \\
\text { forsaken. }\end{array}$ \\
\hline Eat and breed frog & $\begin{array}{l}\text { November 12, } \\
1984\end{array}$ & $\begin{array}{l}\text { - Eating frog is haram according to Imam Syafi'i; is halal according to } \\
\text { Imam Malik; } \\
\text { - Breeding frog for benefit purposes is not contradictive to Islam. }\end{array}$ \\
\hline $\begin{array}{l}\text { Worms and crickets } \\
\text { cultivation }\end{array}$ & April 18, 2000 & $\begin{array}{l}\text { - Justify juristic view (Imam Malik); eating worm is halal under } \\
\text { several condition; } \\
\text { - Worm and cricket cultivation for benefit purposes, not for food, is } \\
\text { not prohibited in Islam. }\end{array}$ \\
\hline $\begin{array}{l}\text { Use of human organs, } \\
\text { placenta, urine for } \\
\text { the medicines and } \\
\text { cosmetics ingredients }\end{array}$ & July 30, 2000 & $\begin{array}{l}\text { - Medicine and cosmetics contain human organs or from the part of } \\
\text { human organs is haram; } \\
\text { - Human urine for medicine is haram; }\end{array}$ \\
\hline $\begin{array}{l}\text { Standardisation of } \\
\text { Fatwa Halal }\end{array}$ & May 25, 2003 & $\begin{array}{l}\text { - Ethanol (C2H5OH) minimum or below } 1 \% \text {, and beverages from } \\
\text { tapai (cassava) juice are including khamar and is haram; } \\
\text { - Component physically separated out from fusel oil of khamar and is } \\
\text { - processed chemically resulting new substance is halal; } \\
\text { - Vinegar from khamar made either naturally of processed is halal; } \\
\text { - Slaughtering animal to be done by Muslim; } \\
\text { - Stunning is permissible; otherwise is prohibited if wounded animal; } \\
\text { - Halal or haram of microbes based on its origin. }\end{array}$ \\
\hline $\begin{array}{l}\text { Halal standard for } \\
\text { cosmetics and the use }\end{array}$ & July 13, 2003 & $\begin{array}{l}\text { - Cosmetics with halal ingredient for make-up is permissible; } \\
\text { - Cosmetics with impure (najis) ingredient except pig is permissible } \\
\text { and to clean up after its usage; } \\
\text { - Cosmetics made from haram or impure ingredients for surgical } \\
\text { procedure (beauty) is haram; } \\
\text { - Cosmetics contains genetically modified microbes involving pig or } \\
\text { human genes is haram; }\end{array}$ \\
\hline Alcohol & $\begin{array}{l}\text { November } \\
18 \text { th, } 2009\end{array}$ & $\begin{array}{l}\text { - Usage of alcohol produced from khamar industry, including by way } \\
\text { chemical synthesis to produce food and beverage is haram; } \\
\text { - Usage of alcohol produced through chemical synthesis to produce } \\
\text { food and beverage is permissible. }\end{array}$ \\
\hline $\begin{array}{l}\text { Certification for } \\
\text { animal slaughtering }\end{array}$ & $\begin{array}{l}\text { December 2, } \\
2009\end{array}$ & $\begin{array}{l}\text { - Standard for slaughtered animal; } \\
\text { - Standard of slaughtering; } \\
\text { - Standard of slaughtering equipment; } \\
\text { - Standard of slaughtering process; } \\
\text { - Standard of processing, storage and shipping. }\end{array}$ \\
\hline
\end{tabular}


Table 3.

List of MUI Fatwa Related to Halal Contemporary Issues (Contd.)

\begin{tabular}{|c|c|c|}
\hline Issues Arisen & Year & Fatwa Decision \\
\hline Microbes & $\begin{array}{l}\text { January 19, } \\
2010\end{array}$ & $\begin{array}{l}\text { - Microbes is halal under certain conditions; } \\
\text { - Microbes contains pig is haram. }\end{array}$ \\
\hline Civet coffee & July 20, 2010 & - Eating and trading civet coffee is halal. \\
\hline $\begin{array}{l}\text { Non-water usage to } \\
\text { wash production tools } \\
\text { contaminate with } \\
\text { unclean material (najis } \\
\text { al-mutawasittah) }\end{array}$ & March 3, 2011 & $\begin{array}{l}\text { - Production tools must not use interchangeably for pork and non- } \\
\text { pork products; } \\
\text { - Production tools contaminate with najis al-mutawasittah is washed } \\
\text { with water; } \\
\text { - In case using water will damage the production tools made from } \\
\text { iron and steel, it is permissible to clean it with other medium. }\end{array}$ \\
\hline $\begin{array}{l}\text { Placenta of halal } \\
\text { animal for cosmetics } \\
\text { and medicines }\end{array}$ & July 20, 2011 & $\begin{array}{l}\text { - Placenta from halal animal for cosmetics and medicines production } \\
\text { is halal; } \\
\text { - Placenta from halal animal carcass for production of cosmetics and } \\
\text { medicines is haram. }\end{array}$ \\
\hline $\begin{array}{l}\text { Achatina fulica for } \\
\text { consumption }\end{array}$ & May 31, 2012 & $\begin{array}{l}\text { - It is haram to eat achatina fulica according to majority jurists; } \\
\text { - It is halal according to Imam Malik if found the benefit. }\end{array}$ \\
\hline $\begin{array}{l}\text { Use of leather, hair } \\
\text { and horn of halal } \\
\text { animal not slaughtered } \\
\text { by way Islam for } \\
\text { food, medicines and } \\
\text { cosmetics }\end{array}$ & $\begin{array}{l}\text { November 7, } \\
2012\end{array}$ & $\begin{array}{l}\text { - It is permissible for cosmetics and non-consumable medicines; } \\
\text { - It is haram for food. }\end{array}$ \\
\hline $\begin{array}{l}\text { Placenta of halal } \\
\text { animal for medicine } \\
\text { ingredients }\end{array}$ & $\begin{array}{l}\text { November 7, } \\
2012\end{array}$ & - It is allowed to use placenta of halal animal for medicine ingredients. \\
\hline
\end{tabular}

Source: Adapted from MUI.

Taken together, MUI which has been existing almost a half century has played a significant role in assisting the country to actualize the values of Islam upon the present situation. In a nutshell, a fatwa is ultimate for the components of the first line of defense in halal governance, and so has Indonesia been performing this with MUI.

\subsection{Control Management}

\subsubsection{Halal Standard of Indonesian Council of Ulama (MUI)}

Halal standard can be defined as a set of documents established by an authorizing body to govern the implementation of halal practice particularly for that of in industry. A halal standard can refer to the design and quality of products, as well as proper conduct of states, organizations, and individuals (Fischer, 2016). A halal standard positions critically in a control management, which is fundamental of the second line of defense in halal governance.

In 5 January 1989, MUI established the Institution for Study of Food, Medicines, and Cosmetics (LPPOM)-MUI to manage halal related matters of the industry practices. This institution is a specialized agency for a halal certification prior to the issuance of JPH. The recognition of LPPOM-MUI as a halal certifying body has been established since 1996 through Memorandum of Cooperation 
Agreement between MUI with the two domestic government agencies. To the time of this study, LPPOM-MUI has issued 11 regulation as its standard governing the industry's practices on halal related matters (LPPOM-MUI).

For the interest of the industry main player, be it a producer, a manufacture or a business owner, LPPOM-MUI as the former halal certifying body has offered its standard called HAS 23000. This document consists of HAS 23000:1 and HAS 23000:2. The first governs the criteria of halal assurance system (HAS), meanwhile, the second administrates policies and procedures related to halal certification requirements. HAS 23000 provides a guideline for manufacturing industry and restaurant, and both of these manuals called Cerol-SS23000 are accessible online (LPPOM-MUI). Table 4 highlights 11 requirements of HAS 23000:1 which are mandatory for halal certification procedures to be prepared by the applicant.

Table 4.

Requirements for Halal Certification Governed under HAS 23000:1

\begin{tabular}{|c|c|}
\hline Requirements & Details \\
\hline Halal policy & $\begin{array}{l}\text { Decision and notification on halal policy by top management for } \\
\text { the firm's stakeholders. }\end{array}$ \\
\hline Halal Management Team & $\begin{array}{l}\text { The team should be formed along with definite duties, } \\
\text { responsibilities and authorities. }\end{array}$ \\
\hline Training and Education & Training procedure must be well documented. \\
\hline Ingredients & $\begin{array}{l}\text { Documents of ingredients for production must exist if } \\
\text { applicable. }\end{array}$ \\
\hline Products & $\begin{array}{l}\text { Name of the product must comply with Islamic values. Retailers } \\
\text { should register all their product names. }\end{array}$ \\
\hline Production Equipment & $\begin{array}{l}\text { Processing industry; no contamination with haram materials; } \\
\text { Restaurant; equipment must only for halal cooking; } \\
\text { Slaughterhouse; only for halal meat production. }\end{array}$ \\
\hline $\begin{array}{l}\text { Documents for Critical } \\
\text { Activity of Production }\end{array}$ & Detail critical activities must be well documented. \\
\hline Traceability & $\begin{array}{l}\text { Written procedure to ensure the halal-ness of the certified } \\
\text { products from the ingredients and the equipment. }\end{array}$ \\
\hline $\begin{array}{l}\text { Well-written Procedures } \\
\text { for Special Case }\end{array}$ & $\begin{array}{l}\text { In case producer also produce non-halal, document stating to } \\
\text { not sell the product for consumers required halal is mandatory. }\end{array}$ \\
\hline Audit internal & $\begin{array}{l}\text { Document of audit internal procedure conducted every } 6 \\
\text { months. }\end{array}$ \\
\hline Management review & $\begin{array}{l}\text { Top management to review the implementation of its halal } \\
\text { policy once a year. }\end{array}$ \\
\hline
\end{tabular}

Source: Adapted from LPPOM-MUI.

Prior to the issuance of JPH, HAS 23000:2 has administrated the procedure of halal certification process in Indonesia. The procedure consists of five stages as illustrated in Figure 4. To either renewal or certify halal a product, an applicant begins with the online registration at www.e-lppommui.org, and submits the 
required documents including payment for registration fee. Following this, LPPOM-MUI shall conduct pre-audit of 4 items; document, product, material and matrix. In case the pre-audit is passed, the applicant is to pay the certification fees covering audit fee, halal certificate fee, fee for assessing the implementation of halal assurance system, fee for halal journal publication, and additional fees for transportation and accommodation of auditor and assessor. LPPOM-MUI should then further conduct audits related procedures once the fee is paid. In case the audit result is approved, a notification of fatwa issuance is forwarded to the fatwa commission of MUI. Following this, a halal certificate along with the standard halal label is further issued (LPPOM-MUI).

Figure 4.

Stages of Halal Certification Process of MUI's HAS 23000:2

\begin{tabular}{|c|c|c|c|c|}
\hline $\begin{array}{c}\text { Stage } 1 \\
\text { (performed by } \\
\text { applicant) }\end{array}$ & $\begin{array}{l}\text { Stage } 2 \\
\text { (performed } \\
\text { by both) }\end{array}$ & $>\begin{array}{l}\text { Stage } 3 \\
\text { (Performed by } \\
\text { LPPOMMUI) }\end{array}$ & $\begin{array}{l}\text { Stage } 4 \\
\text { (Performed } \\
\text { by MUI) }\end{array}$ & $\begin{array}{c}\text { Stage } 5 \\
\text { (performed by } \\
\text { applicant) }\end{array}$ \\
\hline $\begin{array}{l}\text { - Sign up online; } \\
\text { - Halal } \\
\text { registration; } \\
\text { - Registration } \\
\text { fee of Rp. } \\
200.000,00 \\
\text { (USD } \$ 14) ; \\
\text { - Upload } \\
\text { required } \\
\text { documents; } \\
\text { - Submit HAS } \\
\text { questionnaire. }\end{array}$ & $\begin{array}{l}\text { - Pre-audit } \\
\text { performed by } \\
\text { LPPOM-MUI; } \\
\text { - Payment fee } \\
\text { for halal } \\
\text { certification by } \\
\text { applicant; } \\
\text { - Payment } \\
\text { verification by } \\
\text { LPPOM-MUI; } \\
\text { - Pre-audit and } \\
\text { verification } \\
\text { done, applicant } \\
\text { to request } \\
\text { audit schedule. }\end{array}$ & $\begin{array}{l}\text { - Audit is } \\
\text { performed; } \\
\text { - Auditor } \\
\text { meeting; } \\
\text { - Further } \\
\text { checking and } \\
\text { monitoring; } \\
\text { - Approval audit } \\
\text { results. }\end{array}$ & $\begin{array}{l}\text { - Fatwa } \\
\text { notification } \\
\text { recieved; } \\
\text { - Fatwa } \\
\text { Committee } \\
\text { meeting; } \\
\text { - Halal label (as } \\
\text { follows) and } \\
\text { certificate } \\
\text { issuance. }\end{array}$ & $\begin{array}{l}\text { - Halal } \\
\text { certificate to be } \\
\text { donwloaded; } \\
\text { - Further } \\
\text { renewal when } \\
\text { expired. }\end{array}$ \\
\hline
\end{tabular}

Source: Adapted from LPPOM-MUI. The standard of Halal MUI Logo is ruled under LPPOM-MUI regulation No. 11 (SK10/Dir/LPPOMMUI/XII/07).

Halal assurance system in Indonesia has been integrated with the consumers' interest. In this, LPPOM-MUI has launched a phone based application system which is HAS 23106 for IOS, and HAS 23202 for Android, a website page http://www.halalmui.org and a call center service 'Halo LPPOM 14056', where publics can check the status of halal-ness a product easily (LPPOM-MUI). This initiative of MUI has brought a massive benefit for Indonesian consumers who are majority Muslims. Confirming this, Sayogo (2018) investigated the usefulness and importance of online traceability of the halal products among 188 Indonesian Muslims.

In a summary, LPPOM-MUI has controlled halal related matters of the industry practices in Indonesia. It offers a comprehensive halal standard for both producers and consumers interests. In international level, this standard has been widely recognized and become the reference for the practice of several countries (Wilson et al., 2013). Meanwhile in the national context, this standard has played 
a significant contributor for the second defense in halal governance practices. Inasmuch as the hands-on knowledge and the advanced system of LPPOM-MUI, does make sense should LPPOM-MUI be appointed as BPJPH for efficient and effective practices in the national halal certification.

\subsubsection{Foreign Halal Certifying Agency Approved by MUI}

Indonesia has the fourth biggest population worldwide with approximately $82 \%$ Muslims (Kettani, 2010), of so the Country has played a critical position in the international trade. The import policy has been implemented to maintain the national needs (Erwidodo, 2015) of who the exporters from non-Muslim countries has been involving so. With Muslim is the most populous of Indonesian, thus, halal always becomes a serious issue.

LPPOM-MUI has offered a service related to halal certificate recognition embracing such the industry demand. In this, the three categories of the recognition cover slaughtering, raw materials and flavor have been offered with the agreement period shall due within 2 years. Even so, LPPOM-MUI has the right to further investigate the documents of foreign products with the recognized halal certificate for clarification purposes.

Table 5.

Foreign Halal Certifying Agencies Approved by LPPOM-MUI

\begin{tabular}{|c|c|c|c|c|}
\hline \multirow{2}{*}{ Continents } & \multirow{2}{*}{ Approved Agencies } & \multicolumn{3}{|c|}{ Approved Categories } \\
\hline & & Slaughtering & Raw Material & Flavour \\
\hline \multirow{13}{*}{ Asia } & Majelis Ugama Islam Singapore (MUIS) & $\checkmark$ & $\checkmark$ & $\checkmark$ \\
\hline & Jabatan Kemajuan Islam Malaysia (JAKIM) & $\checkmark$ & $\checkmark$ & $\checkmark$ \\
\hline & $\begin{array}{l}\text { Bahagian Kawalan Makanan Halal Jabatan } \\
\text { Hal Ehwal Syariah }\end{array}$ & $\checkmark$ & & \\
\hline & $\begin{array}{l}\text { Muslim Professional Japan Association } \\
\text { (MPJA) }\end{array}$ & $\checkmark$ & $\checkmark$ & \\
\hline & The Japan Moslem Association (JMA) & & $\checkmark$ & $\checkmark$ \\
\hline & $\begin{array}{l}\text { Taiwan Halal Integrity Development } \\
\text { Association (THIDA) }\end{array}$ & $\checkmark$ & $\checkmark$ & \\
\hline & Jamiat Ulama Halal Foundation (India) & $\checkmark$ & & \\
\hline & Jamiat Ulama I-Hind Halal Trust (India) & $\checkmark$ & & \\
\hline & $\begin{array}{l}\text { Asia Pacific Halal Council Co Ltd (APHC) } \\
\text { (Hongkong) }\end{array}$ & $\checkmark$ & $\checkmark$ & \\
\hline & $\begin{array}{l}\text { The Central Islamic Committee of Thailand } \\
\text { (CICOT) }\end{array}$ & $\checkmark$ & $\checkmark$ & \\
\hline & Halal Certification Agency (HCA) (Vietnam) & & $\checkmark$ & $\checkmark$ \\
\hline & $\begin{array}{l}\text { Halal Development Institute of the } \\
\text { Philippines (HDIP) }\end{array}$ & & $\checkmark$ & \\
\hline & $\begin{array}{l}\text { Halal Accreditation Council (Guarantee) } \\
\text { Limited (Sri Lanka) }\end{array}$ & & $\checkmark$ & \\
\hline
\end{tabular}


Table 5.

Foreign Halal Certifying Agencies Approved by LPPOM-MUI (Contd.)

\begin{tabular}{|c|c|c|c|c|}
\hline \multirow{2}{*}{ Continents } & \multirow{2}{*}{ Approved Agencies } & \multicolumn{3}{|c|}{ Approved Categories } \\
\hline & & Slaughtering & Raw Material & Flavour \\
\hline \multirow{10}{*}{$\begin{array}{l}\text { Australia \& } \\
\text { New Zealand }\end{array}$} & $\begin{array}{l}\text { The Islamic Coordinating Council of Victoria } \\
\text { (ICCV) Australia }\end{array}$ & $\checkmark$ & $\checkmark$ & $\checkmark$ \\
\hline & $\begin{array}{l}\text { Supreme Islamic Council of Halal Meat in } \\
\text { Australia Inc. (SICHMA) }\end{array}$ & $\checkmark$ & $\checkmark$ & \\
\hline & $\begin{array}{l}\text { Australian Halal Development \& } \\
\text { Accreditation (AHDAA) }\end{array}$ & $\checkmark$ & & \\
\hline & $\begin{array}{l}\text { Global halal Trade Center Pty Ltd (GHTC } \\
\text { Pty.Ltd) }\end{array}$ & $\checkmark$ & $\checkmark$ & \\
\hline & Western Australian Halal Authority (WAHA) & $\checkmark$ & $\checkmark$ & $\checkmark$ \\
\hline & $\begin{array}{l}\text { Australian Halal Authority \& Advisers } \\
\text { (AHAA) }\end{array}$ & $\checkmark$ & $\checkmark$ & \\
\hline & $\begin{array}{l}\text { Global Australian Halal Certification } \\
\text { (GAHC) }\end{array}$ & $\checkmark$ & & \\
\hline & $\begin{array}{l}\text { Asia Pacific Halal Service - New Zealand, Pty } \\
2011 \text { Limited (APHSNZ-Pty } 2011 \text { ltd) }\end{array}$ & & $\checkmark$ & \\
\hline & $\begin{array}{l}\text { Al Kaussar Halal Food Authority (New } \\
\text { Zealand) }\end{array}$ & $\checkmark$ & $\checkmark$ & \\
\hline & $\begin{array}{l}\text { The Federation of Islamic Association of New } \\
\text { Zealand, Inc (FIANZ) }\end{array}$ & $\checkmark$ & & \\
\hline \multirow{14}{*}{ Europe } & $\begin{array}{l}\text { Halal Food Council of Europe (HFCE) } \\
\text { (Belgium) }\end{array}$ & $\checkmark$ & $\checkmark$ & $\checkmark$ \\
\hline & $\begin{array}{l}\text { The Muslim Religious Union of Poland } \\
\text { (MRU) (Poland) }\end{array}$ & $\checkmark$ & $\checkmark$ & \\
\hline & $\begin{array}{l}\text { Halal Quality Control (HQC) (The } \\
\text { Netherlands and Germany) }\end{array}$ & $\checkmark$ & $\checkmark$ & $\checkmark$ \\
\hline & $\begin{array}{l}\text { Instituto Halal De Junta Islamica (Halal } \\
\text { Institute of Spain) }\end{array}$ & $\checkmark$ & $\checkmark$ & \\
\hline & World Halal Authority (WHA) (Italy) & $\checkmark$ & $\checkmark$ & $\checkmark$ \\
\hline & $\begin{array}{l}\text { Total Quality Halal Correct Certification } \\
\text { (TQHCC) (Netherland) }\end{array}$ & $\checkmark$ & $\checkmark$ & $\checkmark$ \\
\hline & HALAL CONTROL (Germany) & & $\checkmark$ & $\checkmark$ \\
\hline & Halal Certification Europe (HCE) (England) & & $\checkmark$ & \\
\hline & Halal Food Authority (HFA) - UK & $\checkmark$ & $\checkmark$ & \\
\hline & $\begin{array}{l}\text { Halal Feed and Food Inspection Authority } \\
\text { (HFFIA) (The Netherlands) }\end{array}$ & & $\checkmark$ & $\checkmark$ \\
\hline & $\begin{array}{l}\text { Halal Certification Services (HCS) } \\
\text { (Switzerland) }\end{array}$ & $\checkmark$ & $\checkmark$ & $\checkmark$ \\
\hline & Eurasia Halal Services Centre (Turkey) & & $\checkmark$ & \\
\hline & $\begin{array}{l}\text { HAFSA Halal Certification and Food } \\
\text { Imp\&Exp Ltd (Turkey) }\end{array}$ & & $\checkmark$ & \\
\hline & Islamic Foundation of Ireland (IFI) & $\checkmark$ & $\checkmark$ & \\
\hline
\end{tabular}


Table 5.

Foreign Halal Certifying Agencies Approved by LPPOM-MUI (Contd.)

\begin{tabular}{lllcc}
\hline \multirow{2}{*}{ Continents } & \multicolumn{1}{c}{ Approved Agencies } & \multicolumn{3}{c}{ Approved Categories } \\
\cline { 2 - 5 } & \multicolumn{1}{c}{ Slaughtering } & Raw Material & Flavour \\
\hline \multirow{5}{*}{ Aslamic Services of America (ISA) } & $\checkmark$ & $\checkmark$ & $\checkmark$ \\
\cline { 2 - 5 } & Halal Transaction of Omaha & $\checkmark$ & $\checkmark$ & $\checkmark$ \\
\cline { 2 - 5 } & $\begin{array}{l}\text { The Islamic Food and Nutrition Council of } \\
\text { America (IFANCA) }\end{array}$ & $\checkmark$ & $\checkmark$ & \\
\cline { 2 - 5 } & Halal Food Council USA (HFC USA) & $\checkmark$ & $\checkmark$ & $\checkmark$ \\
\cline { 2 - 5 } & American Halal Foundation (AHF) & $\checkmark$ & $\checkmark$ & \\
\cline { 2 - 5 } & $\begin{array}{l}\text { Federation of Muslims Associations in Brazil } \\
\text { (FAMBRAS) }\end{array}$ & $\checkmark$ & $\checkmark$ & \\
\cline { 2 - 5 } & $\begin{array}{l}\text { Islamic Dissemination Centre for Latin } \\
\text { America (CDIAL) Brazil }\end{array}$ & $\checkmark$ & $\checkmark$ & \\
\hline South Africa & $\begin{array}{l}\text { National Independent Halal Trust (NIHT) } \\
\text { South Africa }\end{array}$ & $\checkmark$ & & $\checkmark$ \\
\hline Source: Simplified from LPPOM-MUI. & & & \\
\end{tabular}

Currently, there are about 45 halal certifying agencies worldwide whose the certificates are recognized by LPPOM-MUI. These agencies are from 26 countries consist of 36 agencies approved for slaughtering, 38 agencies for raw materials, and 17 bodies for flavor. The information of Table 5 is per October 2018, and is subject to further update (LPPOM-MUI).

\subsection{Inspection and Enforcement}

\subsubsection{Authorized Inspecting Body}

An inspection is important for securing regulatory quality (Monk, 2012) by critically appraising the materials or items through an examination, measurement and comparison (Business Dictionary). Meanwhile, an enforcement is to make sure a standard is properly followed (Black's Law Dictionary). Inspection and enforcement are critical in the third line of defense in halal governance to ensure halal related act, regulation, fatwa, and standard are appropriately performed.

In halal supply chain of food industry, a halal supervisor plays significantly to ensure its proper implementation. Fuseini, et al. (2017) documented the breaches of halal meat supply chain in the United Kingdom (UK), including illegal slaughter, mislabeling and contamination of halal meat. Given a supply chain is vital for halal enforcement, Soon, Chandia, \& Regenstein (2017) asserted the importance of halal integrity and formally defined it as the assurance of safe (pure), quality (good) and free from mal-practice (lawful) food from farm to fork. In like manner, Ali, Tan, \& Ismail (2017) proposed an integrity framework for halal food supply chain covering raw material, production, service and information integrity.

The sustainability of a halal value chain can be maintained through traceability system (Poniman et al., 2015), and halal clusters (Tieman, 2015). A halal cluster consists of five pillars which are Muslim consumers, education and research, 
halal integrity network, halal supply chain and enablers (Tieman, 2015). Among the critical factors of halal supply chain are government support, transportation planning, information technology, human resource, collaborative work, halal certification and halal traceability (Ab Talib \& Ai Chin, 2018). Ahmad et al. (2018) noted one of the biggest challenges in halal inspection and enforcement is the fraud of halal certification, be it either forgery of halal logo or self-made halal label. In Indonesia, the agency related to halal inspection and enforcement is detailed in Table 6.

Table 6.

Halal Inspection and Enforcement Agencies in Indonesia

\begin{tabular}{|c|c|c|c|}
\hline \multicolumn{2}{|c|}{ Agency } & \multirow{2}{*}{$\begin{array}{l}\text { Scope } \\
\begin{array}{l}\text { Hold main responsible to conduct halal } \\
\text { assurance system (HAS) }\end{array}\end{array}$} & \multirow{2}{*}{$\begin{array}{l}\text { Governed under } \\
\text { Halal Act No. } 33 \\
\text { Article } 5\end{array}$} \\
\hline \multirow{4}{*}{ 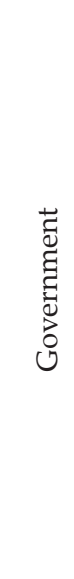 } & $\begin{array}{l}\text { Ministry of Religious } \\
\text { Affairs (Kemenag) }\end{array}$ & & \\
\hline & BPJPH Centre & $\begin{array}{l}\text { - Formed by Kemenag; } \\
\text { - Establish local representative; } \\
\text { - Issue and revoke a Halal certificate; } \\
\text { - Others related duties as governed } \\
\text { under Act No. } 33 \text {. }\end{array}$ & $\begin{array}{l}\text { Halal Act No. } 33 \\
\text { Article } 6\end{array}$ \\
\hline & $\begin{array}{l}\text { Agency for } \\
\text { Consumer Dispute } \\
\text { Settlement (BPSK) }\end{array}$ & $\begin{array}{l}\text { Enforce a criminal sanction, } \\
\text { including on halal fraud. }\end{array}$ & $\begin{array}{l}\text { Act No. 8/1999 } \\
\text { Article } 62\end{array}$ \\
\hline & $\begin{array}{l}\text { National Agency } \\
\text { of Standardization } \\
\text { (BSN) }\end{array}$ & - Including laboratory accreditation. & Act No. 20/2014 \\
\hline \multirow{3}{*}{ 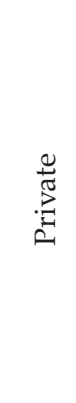 } & $\mathrm{LPH}$ & $\begin{array}{l}\text { Assist BPJPH in inspection and } \\
\text { testing the halal-ness of a product. }\end{array}$ & $\begin{array}{l}\text { Halal Act No. } 33 \\
\text { Article } 12\end{array}$ \\
\hline & MUI & $\begin{array}{l}\text { - Certify Halal Auditor; Decide the } \\
\text { halal-ness a product; and Conduct } \\
\text { accreditation of LPH. }\end{array}$ & $\begin{array}{l}\text { Halal Act No. } 33 \\
\text { Article } 10\end{array}$ \\
\hline & Halal Auditor & $\begin{array}{l}\text { - Appointed and dismissed by LPH; } \\
\text { - Conduct audit programs during the } \\
\text { process of halal certification; } \\
\text { - Report to LPH. }\end{array}$ & $\begin{array}{l}\text { Halal Act No. } 33 \\
\text { Article } 14\end{array}$ \\
\hline \multirow{3}{*}{ 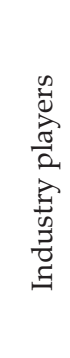 } & Halal Supervisor & $\begin{array}{l}\text { - Hired by a firm and is reported to } \\
\text { BPJH. } \\
\text { - Supervise halal-ness during } \\
\text { production of a firm. }\end{array}$ & $\begin{array}{l}\text { Halal Act No. } 33 \\
\text { Article } 28\end{array}$ \\
\hline & $\begin{array}{l}\text { Internal Auditor for } \\
\text { Halal }\end{array}$ & $\begin{array}{l}\text { - Conduct internal audit for internal } \\
\text { control of halal assurance system. }\end{array}$ & HAS 23000 \\
\hline & $\begin{array}{l}\text { Halal Team } \\
\text { Management }\end{array}$ & - Formed by a firm. & HAS 23000 \\
\hline
\end{tabular}

Source: Adapted from related documents. 
More than a few frauds of halal had hit the local market of Indonesia such as; the foreign products with fake halal label (Detik Food, 2015), and the unauthorized use of the halal label (Kompas, 2016; Viva News, 2017). In Indonesia, a sentence for halal fraud is governed under the Consumer Protection Act No. 8/1999 Article 62, and Halal Act. No. 33/2014 Article 56. The Article 62 of Consumer Protection Act controls the industry upon a penalty for those who label halal their products but not produce by way halal, while the Article 56 of JPH administrates penalty for those whose products already certified halal but fail to maintain the halal-ness of the production process.

\subsubsection{Laboratory}

Laboratory is mandatory in halal food industry to detect any contamination in food. With this, any doubt among Muslim consumers is further clarified and to some extent the transparency, confidence and trust towards a product are delivered for both public and authority (Jaswir et al., 2016). The finding from a laboratory test shall assist law enforcement, process of food safety, quality, policy and decision making (Ahmad et al., 2018).

In Indonesia, LPPOM-MUI's laboratory is the first laboratory for testing polymerase chain reaction (PCR) porcine DNA which has certified ISO17025. The laboratory offers the services of pigskin identification, water penetrating power testing, ethanol content measurement, and pig protein contamination testing (LPPOM-MUI). A laboratory is critical in the third line of defense in halal governance. As such, its further upgrading and accreditation are advisable.

Forasmuch as the latest system of a laboratory is important, Ahmad et al. (2018) explained the controversial case of Cadbury Malaysia in 2014. In brief, the porcine DNA, which was found on the product during the inspection, was tested with a non-accredited laboratory. From there, the related authority utilizing the latest accredited laboratory system conducted a further test. With the newest test, the product was confirmed of free from the DNA (Ahmad et al., 2018). From that, a lesson can learn upon the accuracy of the up-to-date laboratory system.

\subsection{Information, Education and Communication (IEC)}

Information, education and communication (IEC) can help creating responsiveness and propagating the information of the advantages available under the various schemes or programs conducted by a government agency, and can guide the citizen to access them (MOHFW, 2016). IEC is significant for enhancing a consumer's awareness of a halal product (Ahmad et al., 2018). A halal IEC is fundamental of the last defense in halal governance. It involves an institution concerns on halal with some areas of specialization.

In Indonesia, a Halal IEC is established under the form of a university holding, an NGO, and a firm's initiative. Currently, an approximately of 18 agencies of halal IEC are operating in Indonesia. The service offered is varied including a formal education, a training program, a consultative work, a research service, a product development, a business partner, an advocacy of halal, and an LPH service. The oldest halal IEC in Indonesia is Pusat Kajian Sains Halal of Bogor Agriculture 
University (HalalIPB). Meanwhile, some IECs such as Pusat Halal UPI, H-Trend, HTC, P4H, Halal Centre UMM and some others as in Table 7, were just established in the recent years reacting to the market demand.

Table 7.

List of Institution for Halal Information, Education and Communication (IEC) in Indonesia

\begin{tabular}{|c|c|c|}
\hline Name of Institution & Areas & Website \\
\hline LPPOM-MUI & $\begin{array}{l}\text { The pioneer in halal IEC in } \\
\text { Indonesia (NGO). }\end{array}$ & www.halalmui.org \\
\hline $\begin{array}{l}\text { Pusat Kajian Sains Halal } \\
\text { Institute Pertanian Bogor }\end{array}$ & $\begin{array}{l}\text { Research, education, training, } \\
\text { publication, seminar, workshop } \\
\text { and laboratory services } \\
\text { (University). }\end{array}$ & http://halal.ipb.ac.id/ \\
\hline $\begin{array}{l}\text { Institute Teknologi Sepuluh } \\
\text { Nopember (ITS) } \\
\end{array}$ & Halal research center (University) & $\begin{array}{l}\text { https://www.its.ac.id/id/riset/ } \\
\text { fokus-riset/kajian-halal/ }\end{array}$ \\
\hline $\begin{array}{l}\text { Institute Teknologi Bandung } \\
\text { (ITB) }\end{array}$ & Halal research center (University) & $\begin{array}{l}\text { https://www.itb.ac.id/pusat-kajian- } \\
\text { halal }\end{array}$ \\
\hline $\begin{array}{l}\text { UI Halal Centre } \\
\text { University of Indonesia }\end{array}$ & $\begin{array}{l}\text { - Halal advocacy; } \\
\text { - Serves as LPH. }\end{array}$ & $\begin{array}{l}\text { https://dppu.ui.ac.id/ukk- } \\
\text { pengabdian-masyarakat/ } \\
\text { univesitas-indonesia/halal-center/ }\end{array}$ \\
\hline Kampus Managemen Halal & Diploma in halal related education & $\begin{array}{l}\text { https://kampusmanajemenhalal. } \\
\underline{\text { com/ }}\end{array}$ \\
\hline $\begin{array}{l}\text { Halal Thayyib Science Centre } \\
\text { Universitas Brawijaya }\end{array}$ & $\begin{array}{l}\text { - Halal Study; } \\
\text { - Serves as LPH. }\end{array}$ & http://lppm.ub.ac.id/pusat-studi/ \\
\hline $\begin{array}{l}\text { Universitas Gadjah Mada } \\
\text { Islamic Economy and Halal } \\
\text { Industry } \\
\end{array}$ & $\begin{array}{l}\text { Offers Master degree and Ph.D in } \\
\text { halal industry }\end{array}$ & $\begin{array}{l}\underline{\text { http://ekis.pasca.ugm.ac.id// }} \\
\text { tentang-kami/visi-dan-misi// }\end{array}$ \\
\hline $\begin{array}{l}\text { Pusat Halal UPI } \\
\text { Universitas Pendidikan } \\
\text { Indonesia }\end{array}$ & $\begin{array}{l}\text { - Halal education; } \\
\text { - Halal research and product } \\
\text { development; } \\
\text { - Serves as LPH. }\end{array}$ & http://www.upi.edu/ \\
\hline $\begin{array}{l}\text { Pusat Kajian Halal Undip } \\
\text { Universitas Diponegoro }\end{array}$ & Halal research center. & http://pkh.undip.ac.id// \\
\hline $\begin{array}{l}\text { Halal Centre Unair } \\
\text { Universitas Airlangga } \\
\end{array}$ & $\begin{array}{l}\text { Halal research and product } \\
\text { development. }\end{array}$ & https://halal.unair.ac.id/ \\
\hline $\begin{array}{l}\text { Halalan Thayyiban Research } \\
\text { and Education (H-Trend) } \\
\text { Universitas Islam Indonesia }\end{array}$ & Halal research and education. & http://uii.ac.id/ \\
\hline $\begin{array}{l}\text { Pusat Pengkajian dan } \\
\text { Pengembangan Produk Halal } \\
\text { (P4H) } \\
\text { Universitas Islam Negeri } \\
\text { Syarif Hidayatullah }\end{array}$ & $\begin{array}{l}\text { Halal research and product } \\
\text { development. }\end{array}$ & $\underline{\text { www.uinjkt.ac.id }}$ \\
\hline
\end{tabular}


Table 7.

List of Institution for Halal Information, Education and Communication (IEC) in Indonesia (Contd.)

\begin{tabular}{lll}
\hline Name of Institution & \multicolumn{1}{c}{ Areas } & \multicolumn{1}{c}{ Website } \\
\hline $\begin{array}{l}\text { Halalan Thayyiban } \\
\text { Centre (HTC) Universitas }\end{array}$ & Halal education. & $\underline{\text { http://www.umy.ac.id/ }}$ \\
Muhammadiyah Yogyakarta & & $\underline{\text { http://www.umm.ac.id/ }}$ \\
\hline Halal Centre UMM & • Halal education; & \\
Universitas Muhammadiyah & - Serves as LPH. & \\
Malang & & $\underline{\text { Mww.idhalalcenter.org }}$ \\
\hline $\begin{array}{l}\text { Indonesia Halal Lifestyle } \\
\text { Centre }\end{array}$ & partner (NGO). & $\underline{\text { http://halalwatch.or.id }}$ \\
\hline Indonesia Halal Watch & Halal advocates (NGO). Consultation, Business & $\underline{\text { sttp://www.safiindonesia.com/ }}$ \\
\hline Safi Research Institute & Specialized at halal cosmetics (NGO)archinstitute/\#sri \\
\hline
\end{tabular}

Source: Adapted from related documents.

With the number of halal fraud gets increasing nowadays, a halal IEC is further challenged to provide a preventive measure in the future practice (Ahmad et al., 2018). In one particular case of halal fraud which had happened in Indonesia reported by Republika (2014), was claimed due to a lack of halal education. The report asserted the critical role of the government in halal education and promotion in consideration of the cost reason. For that, the interviewee of the report urged that State Budget should be planned for the purposes of halal education and a massive publication (Republika, 2014).

\section{CONCLUSION AND RECOMMENDATION}

\section{a. Conclusion}

This study was undertaken to review in detail the information of the practice of halal governance in Indonesia. In doing so, the method of qualitative documentary was employed to study the subject matters. This paper has firstly identified the four themes of halal governance. From that, the explanation upon lines of defense in halal governance was established. As such, the present paper further reviewed the information available online related to that of the practices in Indonesia. Ultimately, a comprehensive insight of the practices was systematically documented.

One of the most noteworthy findings emerging from this study is the highlight of the current issues related to the halal governance practices in Indonesia, together with the hands-on recommendation for advancing the practices. These findings are relevant for the related government agencies, practitioners, and academics. To some extent, hopefully this further assists the country to achieve the target of leading the global halal industry. Additionally, the present discussion has also contributed for our understanding of halal governance theory by establishing the 
term of halal governance. With so, the present paper is the first study to detail its lines of defense, and to review comprehensively that of the practices from the Indonesia's context.

\section{b. Recommendation}

The article 29 of JPH governs the first application of halal certification is done by a written text submitted to BPJPH. This means the first procedure, perhaps, should be done manually offline. With the existing advanced online system of LPPOMMUI for the service, the appointment of LPPOM-MUI as BPJPH is therefore reasonable for cutting the red-tape purposes, and most importantly for effective and efficient practices. This shall be one voice with a single window certification as per recommended by Limenta et al. (2018). Shortly, it is advisable for the regulator to harmonize the issued policy with the current system to make the law compatible with the current circumstances.

Apart from the above, given this research is preliminary for studying halal governance, thus a further elaboration related to the theory is recommended. A future work may employ another qualitative approach, for instance; an interview with the main players, to get direct insight into the subject matters, particularly in exploring that of the specific case of one particular object.

\section{REFERENCES}

Ab Talib, M. S., \& Ai Chin, T. (2018). Halal Food Standard Implementation: Are Malaysian Firms Proactive Or Reactive? British Food Journal, 120(6), 1330-1343. https://doi.org/10.1108/BFJ-07-2017-0366

Adam, P. (2017). Kedudukan Sertifikat Halal Dalam Sistem Hukum Nasional Sebagai Upaya Perlindungan Konsumen Dalam Hukum Islam. https:// ejournal.unisba.ac.id/index.php/amwaluna/article/view/2172

Ahmad, A. N., Ungku Zainal Abidin, U. F., Othman, M., \& Abdul Rahman, R. (2018). Overview Of The Halal Food Control System In Malaysia. Food Control, 90, 352-363. https://doi.org/10.1016/j.foodcont.2018.02.035

Ali, M. H., Tan, K. H., \& Ismail, M. D. (2017). A Supply Chain Integrity Framework For Halal Food. British Food Journal, 119(1), 20-38. https://doi.org/10.1108/BFJ07-2016-0345

Anwar, M. K., Fahrullah, A., \& Ridlwan, A. A. (2018). The Problems of Halal Certification. http://www.iaeme.com/ijciet/issues.asp?JType=IJCIET\&VType= 9\&IType $=8$

Black's Law Dictionary. (n.d.). What is Technical Information? Definition Of Technical Information (Black's Law Dictionary). Retrieved October 9, 2018, from https://thelawdictionary.org/technical-information/

Bowen, G. A. (2009). Document Analysis as a Qualitative Research Method. Qualitative Research Journal Document Analysis as a Qualitative Research Method (Vol. 9). https://doi.org/10.3316/qrj0902027

Business Dictionary. (n.d.-a). What Is A Regulation? Definition and Meaning - Businessdictionary.Com. Retrieved October 5, 2018, from http://www. businessdictionary.com/definition/regulation.html 
Business Dictionary. (n.d.-b). What is Inspection? Definition and Meaning - BusinessDictionary.com. Retrieved October 9, 2018, from http://www. businessdictionary.com/definition/inspection.html

Business Dictionary. (2018). What is Governance? Definition and Meaning - BusinessDictionary.com. Retrieved October 2, 2018, from http://www. businessdictionary.com/definition/governance.html

Cambridge Dictionary. (n.d.). Legislation Meaning in the Cambridge English Dictionary. Retrieved October 5, 2018, from https://dictionary.cambridge.org/ dictionary/english/legislation

Cambridge Dictionary. (2018). Governance Meaning in the Cambridge English Dictionary. Retrieved October 2, 2018, from https://dictionary.cambridge.org/ dictionary/english/governance

Creswell, J. W. (2012). Educational research: Planning, Conducting, and Evaluating Quantitative and Qualitative Research. Educational Research (Vol. 4). https://doi. org/10.1017/CBO9781107415324.004

Detik Finance. (2011). Hatta: Indonesia Serius Jadi Pusat Halal Dunia. Retrieved October 3, 2018, from https://finance.detik.com/berita-ekonomibisnis/d-1702173/hatta-indonesia-serius-jadi-pusat-halal-dunia

Detik Food. (2015). Hati-hati, Banyak Sertifikat Halal Palsu pada Restoran dan Produk Berlabel Halal. Retrieved October 10, 2018, from https://food.detik. com/info-halal/d-2908887/hati-hati-banyak-sertifikat-halal-palsu-padarestoran-dan-produk-berlabel-halal

E. Rios, R., E. Riquelme, H., \& Abdelaziz, Y. (2014). Do Halal Certification Country of Origin and Brand Name Familiarity Matter? Asia Pacific Journal of Marketing and Logistics, 26(5), 665-686. https://doi.org/10.1108/APJML-03-2014-0046

Erwidodo. (2015). Kebijakan Impor, Cadangan Pangan, Stabilisasi Harga dan Ketahanan Pangan Nasional Berkemandirian. Retrieved from http://www.litbang.pertanian. go.id/buku/swasembada/BAB-III-3.pdf

Fischer, J. (2012). Branding Halal: A Photographic Essay on Global Muslim Markets. Anthropology Today, 28(4), 18-21. https://doi.org/10.1111/j.14678322.2012.00886.x

Fischer, J. (2016). Islam, Standards, and Technoscience In Global Halal Zones (First Edition). Routledge Taylor \& Francis.

Folia, R. (2017). Kebijakan Sertifikasi Halal Dinilai Makin Membingungkan. Retrieved October 6, 2018, from https://www.idntimes.com/news/indonesia/ rosa-folia/kebijakan-sertifikasi-halal-dinilai-makin-membingungkan/full

Fuseini, A., Wotton, S. B., Knowles, T. G., \& Hadley, P. J. (2017). Halal Meat Fraud and Safety Issues in the UK: a Review in the Context of the European Union. Food Ethics, (1), 127-142. https://doi.org/10.1007/s41055-017-0009-1

Ginenza, K., \& Hamid, A. (2015). Foundations of Shari'ah Governance of Islamic Banks. Wiley Finance Series.

HalalIPB. (n.d.). Pusat Kajian Sains Halal. Institut Pertanian Bogor. Retrieved October 12, 2018, from http://halal.ipb.ac.id/

Harimurti, H. (2018). BPJPH Belum Berfungsi, Sertifikasi Halal ke MUI Suaramerdeka.com Cyber News. Retrieved October 10, 2018, from https:// www.suaramerdeka.com/news/baca/124107/bpjph-belum-berfungsisertifikasi-halal-ke-mui 
HDCGlobal. (n.d.). Halal Industry Development Corporation - Fatwa. Retrieved October 5, 2018, from http://www.hdcglobal.com/publisher/cdh_fatwa

Jaswir, I., Mirghani, M. E. S., Salleh, H. M., Ramli, N., Octavianti, F., \& Hendri, R. (2016). An Overview of the Current Analytical Methods for Halal Testing. In Contemporary Issues and Development in the Global Halal Industry (pp. 291-300). Singapore: Springer Singapore. https://doi.org/10.1007/978-981-10-1452-9_27

Jaswir, I. (2018). Halal Science: Perkembangan Global dan Potensi Indonesia. https://www.kopertis4.or.id/wp-content/uploads/2018/05/PresentationRistekdikti-May-2018-Bandung.pdf

Jundi, M., \& Imam S. (2017). UU Jaminan Produk Halal Digugat, IHW: Aturan Sertifikasi Halal Sudah Tepat - Kiblat. Retrieved October 6, 2018, from https:// www.kiblat.net/2017/05/30/uu-jaminan-produk-halal-digugat-ihw-aturansertifikasi-halal-sudah-tepat/

Kaufman, L., \& Smith, C. S. (2000). Chinese Pigs Feed a Western Fashion Boom The New York Times. Retrieved October 6, 2018, from https://www.nytimes. com/2000/12/24/business/chinese-pigs-feed-a-western-fashion-boom.html

Kemenag. (2018). Website Kementerian Agama RI. Retrieved October 4, 2018, from https://kemenag.go.id/berita/read/506759/menag-lukman--lppom-mui-rolemodel-sertifikasi-halal-dunia

Kettani, H. (2010). Muslim Population in Asia: 1950 - 2020. International Journal of Environmental Science and Development, 1(2), 143-153. Retrieved from http:// www.ijesd.org/papers/28-D437.pdf

Kompas. (2016). Kemasan Makanan \&quot;Bikini\&quot; Berlabel Halal Palsu Kompas.com. Retrieved October 10, 2018, from https://megapolitan.kompas. com/read/2016/08/08/16475821/kemasan.makanan.bikini.berlabel.halal.palsu

Krippendorff, K. (2004). Content analysis : an introduction to its methodology (2nd ed.). Thousand Oaks: Sage Publication.

Leather Dictionary. (2018). Leather clothing - www.leather-dictionary.com - The Leather Dictionary. Retrieved October 6, 2018, from https:/www.leatherdictionary.com/index.php/Leather_clothing\#Leather_garments_made_of_ goatskin

Lestari, Y. D., Okdinawati, L., \& Simatupang, T. M. (2018). Halal Logistic Business Model Development in Indonesia. International Journal of Supply Chain Management, 7(3), 238-250. https:/ojs.excelingtech.co.uk/index.php/IJSCM/ article/viewFile/1969/pdf

Limenta, M., Edis, B. M., \& Fernando, O. (2018). Disabling Labelling in Indonesia: Invoking WTO Laws in the Wake of Halal Policy Objectives. World Trade Review, 17(3), 451-476. https://doi.org/10.1017/S1474745617000167

LPPOM-MUI. (n.d.). Lembaga Pengkajian Pangan Obat-obatan dan Kosmetika MUI. Retrieved October 8, 2018, from http://www.halalmui.org/mui14/index. php/main/changelang/1/30/30

Maison, D., Marchlewska, M., Syarifah, D., Zein, R. A., \& Purba, H. P. (2018). Explicit versus Implicit "Halal" Information: Influence of the Halal Label and the Country-of-Origin Information on Product Perceptions in Indonesia. Frontiers in Psychology, 9(MAR), 1-7. https://doi.org/10.3389/fpsyg.2018.00382

Majelis Ulama Indonesia. (n.d.). Sejarah MUI - Majelis Ulama Indonesia. Retrieved October 6, 2018, from https://mui.or.id/sejarah-mui/ 
Mehmood, M. I. (2015). Fatwa in Islamic Law, Institutional Comparison of Fatwa in Malaysia and Pakistan: The Relevance of Malaysian Fatwa Model for Legal System of Pakistan. Arts and Social Sciences Journal, 06(03), 1-3. https://doi. org/10.4172/2151-6200.1000118

Mogalakwe, M. (2006). The Use of Documentary Research Methods in Social Research. Retrieved from http://citeseerx.ist.psu.edu/viewdoc/ download?doi=10.1.1.454.5260\&rep=rep1\&type=pdf

MOHFW. (2016). Information, Education Eamp; Communication (IEC). Retrieved from https://mohfw.gov.in/sites/default/files/17563256478856633221.pdf

Monk, J. (2012). Reform of Regulatory Enforcement and Inspections in OECD Countries. Retrieved from https://www.oecd.org/regreform/Reform of inspections - Web - Julie Monk.pdf

Nasaruddin, R. R., Mel, M., Fuad, F., Jaswir, I., \& Hamid, H.A.(2011). The Importance of a Standardized Islamic Manufacturing (IMP) for Food and Pharmaceutical Productions. 2nd International Conference on Professional Ethics $\mathcal{E}$ Education in Engineering 2011, 2011(5), 978-983. https://doi.org/10.13140/2.1.3112.3520

Neuendorf, K. A. (2002). The Content Analysis Guidebook. Thousand Oaks: Sage Publications, Inc.

Nusran, M., Gunawan, Razak, M., Numba, S., \& Wekke, I. S. (2018). Halal Awareness on the Socialization of Halal Certification Halal Awareness on the Socialization of Halal Certification, 0-7. https://iopscience.iop.org/ article/10.1088/1755-1315/175/1/012217

Oxford Islamic Studies. (n.d.). Fatwa - Oxford Islamic Studies Online. Retrieved October 5, 2018, from http://www.oxfordislamicstudies.com/article/opr/t125/ e646

Plano Clark, V. L., \& Creswell, J. W. (2015). Understanding Research: A Consumer's Guide. https://doi.org/13-978-0-13-158389-4

Poniman, D., Purchase, S., \& Sneddon, J. (2015). Traceability Systems in the Western Australia Halal Food Supply Chain. Asia Pacific Journal of Marketing and Logistics, 27(2), 324-348. https://doi.org/10.1108/APJML-05-2014-0082

Prabowo, S., Rahman, A. A., Rahman, S. A., \& Samah, A. A. (2015). Revealing Factors Hindering Halal Certification in East Kalimantan Indonesia. Journal of Islamic Marketing, 6(2), 268-291. https://doi.org/10.1108/JIMA-05-2014-0040

Rafiki, A. (2014). Determinants on the Obtainment of Halal Certification among Small Firms. World Applied Sciences Journal, 32(1), 47-55. https://doi.org/10.5829/ idosi.wasj.2014.32.01.593

Ramli, N. (2010). Laws and Regulations on Halal Production Noriah Ramli - INHART, IIUM USIM-HDC Halal Executive Programme 2010. Retrieved from http:// irep.iium.edu.my/16117/1/HALAL_LEGAL_CONTROL-USIM-HDC_ HEP_1_2010-2.pdf

Republika. (2009). Sertifikasi Halal LPPOM MUI Diakui Dunia. Republika Online. Retrieved October 4, 2018, from https://www.republika.co.id/berita/duniaislam/fatwa/12/01/13/84892-sertifikasi-halal-lppom-mui-diakui-dunia

Republika. (2010). LPPOM MUI: Indonesia sebagai Pusat Halal Dunia. Republika Online. Retrieved October 3, 2018, from https://www.republika.co.id/berita/ republika-tv/ummat/10/05/22/116593-lppom-mui-indonesia-sebagai-pusathalal-dunia 
Republika. (2014). Edukasi Kurang, Label Halal Palsu Marak. Republika Online. Retrieved October 12, 2018, from https://www.republika.co.id/berita/koran/ khazanah-koran/14/12/10/ngd2h213-edukasi-kurang-label-halal-palsu-marak

Saad, S. N. H., Abd Rahman, F., \& Muhammad, A. (2016). An Overview of the Shariah Governance of the Halal Industry in Malaysia : With Special Reference to the Halal Logistics. Journal of Applied Environmental and Biological Sciences, $6(11 S), 53-58$.

Safari. (2018). IHW Minta Presiden 2019 Wujudkan Indonesia Sebagai Pusat Halal Dunia. Retrieved October 3, 2018, from http://nasional.harianterbit. com/nasional/2018/09/12/102117/0/25/IHW-Minta-Presiden-2019-WujudkanIndonesia-Sebagai-Pusat-Halal-Dunia

Satria. (2012). Universitas Gadjah Mada: Wamenag: Indonesia Pusat Halal Dunia. Retrieved October 3, 2018, from https://ugm.ac.id/id/berita/4603-wamenag:. indonesia.pusat.halal.dunia

Sayogo, D. S. (2018). Online Traceability for Halal Product Information: Perceptions of Muslim Consumers in Indonesia. Journal of Islamic Marketing, 9(1), 99-116. https://doi.org/10.1108/JIMA-07-2016-0057

Setiaji, A. T. (2018). Lebih Dari 50 Negara Meminta Sertifikasi Halal MUI Agar Diakui Dunia. Retrieved October 4, 2018, from http://mysharing.co/lebih-dari50-negara-meminta-sertifikasi-halal-mui-agar-diakui-dunia/

Setyawan, F. A. (2016). Pro Kontra Sertifikasi Halal MUI di Baju dan Sepatu: Okezone News. Retrieved October 6, 2018, from https://news.okezone.com/ $\mathrm{read} / 2016 / 03 / 25 / 337 / 1345711 /$ pro-kontra-sertifikasi-halal-mui-di-baju-dansepatu

Situmorang, A. P. (2016). Pro Kontra Pemberlakuan UU Jaminan Produk Halal. Retrieved October 6, 2018, from https://www.merdeka.com/peristiwa/prokontra-pemberlakuan-uu-jaminan-produk-halal.html

Soon, J. M., Chandia, M., \& Regenstein, J. Mac. (2017). Halal Integrity in the Food Supply Chain. British Food Journal, 119(1), 39-51. https://doi.org/10.1108/BFJ04-2016-0150

Sugiarti, S. (n.d.). Potensi Industri Halal Indonesia Capai US\$10 Miliar. Retrieved October 1, 2018, from http://mysharing.co/potensi-industri-halal-indonesiacapai-us-10/

Surya, E. D., Ginting, P., Rini, E. S., Absah, Y., \& Utara, U. S. (2018). The Analysis of Halal Tourism Products and Brand Image Destination on Tourists ' Repeated Visits Via Trust in West Sumatera. http://www.iaeme.com/ijciet/issues. asp?JType=IJCIET\&VType=9\&IType $=8$

Tieman, M. (2015). Halal clusters. Journal of Islamic Marketing, 6(1), 2-21. https:// doi.org/10.1108/JIMA-05-2014-0034

UNESCO. (2018). Concept of governance. United Nations Educational, Scientific and Cultural Organization. Retrieved October 2, 2018, from http://www. unesco.org/new/en/education/themes/strengthening-education-systems/ quality-framework/technical-notes/concept-of-governance/

University of Bradford. (n.d.). What is Critical Analysis? Retrieved from www.brad. ac.uk/academic-skills 
Viva News. (2017). Soal Botol Miras Berlabel Halal, Begini Reaksi MUI VIVA. Retrieved October 10, 2018, from https://www.viva.co.id/berita/ nasional/970277-soal-botol-miras-berlabel-halal-begini-reaksi-mui

Wilson,J.A.J., Belk, R. W., Bamossy, G.J., Sandikci,Ö., Kartajaya,H., Sobh, R., ... Scott, L. (2013). Crescent Marketing, Muslim Geographies and Brand Islam. Journal of Islamic Marketing, 4(1), 22-50. https://doi.org/10.1108/17590831311306336

Wilson, J. A. J., \& Liu, J. (2010). Shaping the Halal into a Brand? Journal of Islamic Marketing, 1(2), 107-123. https://doi.org/10.1108/17590831011055851 
This page is intentionally left blank 